DOI: 10.17148/IARJSET.2021.8934

\title{
Impartially, Conditions and Consignment: Challenges in Inclusive Education-A Review
}

\author{
Mehak Sharma ${ }^{1}$, Dr. Kuldip Kaur Grewal ${ }^{2}$, Dr. Mohua Khosla ${ }^{3}$ \\ ${ }^{1}$ Research Scholar, CT University, Ludhiana. \\ ${ }^{2}$ Professor, Department of Education, School of Humanities and Physical Education, CT University, Ludhiana \\ ${ }^{3}$ Associate Professor, Malwa Central College of Education for women, Ludhiana.
}

\begin{abstract}
During the 1990s, global guide offices suggested that destitution decrease programs explicitly target individuals with inabilities notwithstanding other hindered gatherings, like ladies, booked standings or Dalits and ancestral networks (Asian Development Bank, 2002; World Bank, 2004). These Millennium Development Objectives have given the system to government mediation in India, adding to enactment and projects for comprehensive training as a financially savvy what's more, quality alternative for all — youngsters with incapacities included. However, the National Statistics on individuals with inabilities led in 2002 found that, regardless of these endeavors, about $94 \%$ of kids with inabilities didn't get any instructive administrations, and a few gatherings, like kids in rustic regions, young ladies with inabilities and people with mental hindrance, were further under-addressed (National Test Survey Organization, 2003). What's more, contemplates demonstrating divided execution (Alur, 2002a; Jangira, 2002), vulnerability about the idea of consideration (Singal, 2005, 2006), lacking assets and spread (Jha, 2001, 2004; Mohapatra, 2004) highlighted an absence of value programming.
\end{abstract}

Keywords: Inclusive Education, Peers, Disabilities.

\section{INTRODUCTION}

Verifiably, willful offices have prevailed in help arrangement for individuals with handicaps in India (Misra, 2000; Alur, 2002b). Beginning with Christian evangelists during the 1880s, the cause model turned out to be essential for the unique schools they set up (Alur, 2002b), for example, for the visually impaired in 1887, for 'the Deaf and Mute' in 1888, for 'Disabled Children' during the 1850s, and for the 'intellectually lacking' in 1934 (Misra, 2000).

\section{Advancement of a custom curriculum in India}

Government mediation started during the 1940s during British standard with the Central Warning Board of Education, which made proposals for administration arrangement. In 1947, under the recently autonomous Indian government, the Ministry of Education set up a couple instructive and workshop units for daze grown-ups to learn occupations customarily saw to be appropriate for individuals with visual debilitations, such as stick weaving and music (Bhatt, 1963, refered to in Kalyanpur, 1996). These units were later extended to incorporate individuals with hearing and muscular hindrances. On the entire, nonetheless, the post-Independence government has zeroed in principally on setting up public examination organizations, granting grants and giving money related help to willful offices to build up uncommon schools (Misra, 2000; Alur, 2002b), while the willful or non-administrative associations (NGOs) have proceeded to be answerable for setting up unique schools. As all the examination organizations and most extraordinary schools were situated in metropolitan zones, and numerous NGOs charged expenses, these administrations were difficult to reach to poor people and rustic, comprising a larger part of the populace.

Youngsters with handicaps were 'imperceptible' (Alur, 2002a) in public approach, and the biggest bundle of wellbeing and instruction administrations for youngsters and ladies in country territories, the Integrated Child Development Scheme (ICDS), set up in 1974, did exclude kids with inabilities among its recipients (Alur, 2002a).

\section{Effect of ordinary schooling and the part of global guide offices}

We should likewise take a gander at the more extensive setting to represent the constraints of the early IEDC program. Two reasons are the simultaneous disappointments in the advancement of ordinary schooling, and the part of global guide offices, similar to UNESCO, the World Bank, UNICEF, and all the more as of late, the Asian Development Bank, in coordinating the course of instructive arrangements and projects. In the suspicion that destitution in the recently free countries could be dispensed with on the off chance that they were created in accordance with the 


\title{
International Advanced Research Journal in Science, Engineering and Technology
}

\author{
Vol. 8, Issue 9, September 2021
}

\section{DOI: 10.17148/IARJSET.2021.8934}

industrialized previous colonizing nations, the Western model of monetary improvement turned into the format for development (Malapka, 1992).

Towards this, contributor created nations contributed, fiscally through global help organizations, and in fact through a global specialized help network, to beneficiary non-industrial nations. As a rule, the verifiable, and at times unequivocal, understanding was that beneficiaries of money related help would follow the global guide givers' rules determining how the monies were to be spent (Mattelart, 1983). As a rule, these suggestions depended on rehearses fruitful in benefactor nations and didn't consider the neighborhood socio-world of politics (Brady and Anderson, 1981; Gokhale, 1981; Miles, 1986). More terrible, Dalal (2002) furthermore, Miles (2002) note unfamiliar groups of designers, persuaded that Western logical information was the correct way to advancement, regularly saw nearby social convictions as boundaries instead of qualities. For example, the pattern toward isolated settings in India reflected worldwide improvements in a custom curriculum, paying little heed to the significant levels of common incorporation that won locally (Miles, 1997), and has proceeded even after the isolation and standardization of individuals with inabilities has fallen into unsavoriness in created nations.

In light of global guide organization rules to foster more significant curricular options for the provincial poor, the public authority presented non-formal instruction (NFE) to connect with school dropouts and hindered gatherings, like young ladies and Dalits (Jha, 2004). In spite of its initial guarantee as a feasible alternative (Baine, 1988), inside the furiously aggressive climate of contemporary India (Misra, 2000; Premji, 2005), the insight that it offered a 'watereddown educational program' before long consigned it to optional status, under-financed and of sub-par quality (Jha, 2001, 2004). Further, in light of the accentuation on a specialized curriculum and isolated settings, NFE was not officially fused into programming for youngsters with handicaps.

\section{Handicap and the thousand year's improvement objectives}

At that point in the last part of the 1990s, global guide offices distinguished individuals with inabilities as another weak gathering, taking note of that incapacity is both a reason and a consequence of neediness (Asian Development Bank, 2002; World Bank, 2004). The thousand years improvement objectives suggested that neediness decrease endeavors incorporate people with incapacities alongside as of now focused on gatherings. Hence, handicap turned into a centrestage need in the Indian government's push to diminish destitution. These endeavors included enactment, public mindfulness crusades, and expanded subsidizing.

\section{Enactment}

During the 1990s, the public authority sanctioned three inability related enactments. Reacting to the requirement for limit constructing, the Rehabilitation Council of India (RCI) Act, 1992, made the RCI a legal body towards ordering least principles for preparing and educator accreditation for experts in the field of a specialized curriculum and recovery (Misra, 2000). The Persons with Disabilities (Equal Opportunities, Assurance of Rights and Full Participation) Act of 1995 and the National Trust (for the Welfare of Persons with Autism, Cerebral Palsy, Mental Retardation and Multiple Inabilities) Act of 1999 followed.

Essentially, moving away from the foundation model, the reason of a worldwide rights-based setting (Arieff, 2006) on which the Acts are based isn't really reflected inside the bigger cultural milieu (Miles, 2002; Kalyanpur, 2006a). Studies show that the overall population will in general legitimize addressing the necessities of individuals with incapacities on the premise of 'ehsaan' or commitment (Miles, 2002), while experts in the field do as such on the premise of 'samjhauta' or understanding (Kalyanpur, 2006a). In such an environment, the latest thing of requesting one's privileges and participatory turn of events, while a apparently fair methods for enabling recipients, may really force promotion assumptions that smack of oppression (Cooke and Kothari, 2001) and offer a way of talking that isn't open to the conventional public, further underestimating individuals with handicaps. The way that the public authority itself has flopped hopelessly in attempting to guarantee that the privileges, everything being equal, to schooling are maintained likewise delivers the way of talking futile (Deepa, 2006).

Researchers likewise contend that the laws give not many points of interest on execution (Alur, 2002b; Jha, 2004) and center more around corrective measures for infringement than on offering impetuses for consistence (Mohapatra, 2004). For one, a portion of the orders negate one another (Alur, 2002b), while others cover (Jha, 2004). For example, while the PWD Act advances incorporation, the National Trust Act advances isolation, with its prerequisite that offices for people with incapacities incorporate private lodgings furthermore, homes, and, likewise, the RCI Act keeps on requiring separate preparing programs for uncommon and general teachers (Singal, 2005). In different cases, assertsJha (2004), there is a feeling of 're-imagining the wheel', where the enactments are as it were insignificantly not quite the same as one another. For another, state governments have contrasting needs. For example, as per the legitimate command, the focal government initiated the state office of Disability Commissioners in 1998 to work with organization furthermore, execution. Nonetheless, just nine states have really selected free inability officials (Asian Development Bank, 2002). 


\title{
International Advanced Research Journal in Science, Engineering and Technology
}

\author{
Vol. 8, Issue 9, September 2021
}

\section{DOI: 10.17148/IARJSET.2021.8934}

\section{Public mindfulness crusades}

The PWD Act's command for media inclusion on incapacity related issues gives the Service of Information and Broadcasting the obligation regarding public mindfulness and instruction programs ('Films and radio projects', 2005). Thus, driving papers and magazines convey articles on issues identifying with handicap routinely, governmentsubsidized announcements and divider banners giving fundamental data on avoidance through immunization and early distinguishing proof figure unmistakably in both rustic and metropolitan zones, and motion pictures about individuals with inabilities, like Black and Iqbal, have contacted wide crowds and gotten mainstream approval (Paul, 2005). Under the Ministry of Social Justice and Empowerment (MSJE), the Rehabilitation Council (2005) has embraced workshops and gatherings to teach NGOs and the media about accessible projects and expected recipients, fostered a handbook on incapacity the board to instruct officials in the common managerial administrations, and is fostering a comparative one for writers. At last, the public authority financed program to give helps and apparatuses and head out concessions to people affirmed as incapacitated, furthermore, its order for a boundary free climate has expanded the perceivability of grown-ups with actual inabilities on metropolitan roads (Pinglay, 2005).

\section{Government financing}

Government has likewise put forth attempts to reserve assets towards incapacity and recovery programs (for an inside and out survey, see Mohapatra, 2004). As an arranged economy, the Indian government extends these designations at customary 5-year stretches, called Five-Year Plans. Through the initial four Five-Year Plans, allotments for advancement were focused on generally at country territories. A shift towards incorporating individuals with handicaps started uniquely during the 1970s. The principal upsurge of financing went to NGOs furthermore, to building up the public exploration establishments during the fifth Five-Year Plan (1974-78). A subsequent increment happened in the eighth and ninth Plans (1992-2002), zeroing in on government-supported schools, which brought about the push towards comprehensive schooling. The expenses for the 10th Plan (2002-07) are the most elevated to date, reflecting the World Bank (2004) and Asian Development Bank (2002) orders to incorporate individuals with incapacities in neediness decrease programs and the order to submit 3\% of all assets assigned for provincial advancement towards people with handicaps.

\section{Restricted instructive assistance arrangement}

The NSSO initially endeavored to gather data on the quantity of people with actual incapacities in 1960; this exertion was exploratory and limited to provincial regions (NSSO, 2003). In 1961, the review was stretched out to incorporate metropolitan territories also, yet these 'early requests' were neither orderly nor thorough. Resulting adjusts gathered information on the pervasiveness and rate of inability in the nation and reached out to incorporate people with visual, correspondence (for example hearing and additionally discourse) furthermore, locomotor handicaps. It was distinctly in the latest round, in 2002, that people with mental inability were remembered for the check. The most complete study to date, it likewise gives data on a few other indicators.

From this study (NSSO, 2003), we discover that the complete number of individuals with inabilities in the nation is 18.49 million, comprising about $1.8 \%$ of the aggregate populace. As far as instructive levels, just $11 \%$ of youngsters with incapacities between the ages of 5-18 years in metropolitan territories (under $1 \%$ in country regions) were taken on exceptional schools, while $55 \%$ of grown-ups with incapacities were ignorant $(59 \%$ in provincial and $40 \%$ in metropolitan zones) with just $7 \%$ in rustic and $18 \%$ in metropolitan territories having finished auxiliary training. Young ladies with incapacities had lower enrolment proportions than young men with inabilities (1) across area, for example metropolitan and country, (2) by kind of tutoring, for example standard and exceptional schools, and (3) by level, for example essential and optional of all the incapacity categories, 3 people with mental hindrance were most unrealistic to have gotten a training, had the most reduced enrolment proportion in schools, were the least extent of utilized grownups and were the destined to stay unmarried

\section{Marking measure}

The issue of marking has produced extensive discussion somewhere else. Researchers attest that the clinical model which overwhelms the distinguishing proof and naming measure is defective in that it expects the incapacity to be a shortfall inside the person recognizable to a natural premise, that incapacity is a level headed, quantifiable build, and that understandings of handicap are general, paying little heed to social standards (Harry and Klingner, 2006; Rao, 2006). An investigation of the socioeconomics uncovers certain errors furthermore, ambiguities that recommend that the count interaction, which utilizes this model, is likewise imperfect.

On the off chance that we analyze the pervasiveness and rate rates, we find that at $1.85 \%$, the predominance of incapacity is possibly higher in provincial than in metropolitan regions (1.5\%), while the frequency rate (or the quantity of individuals whose beginning of incapacity happened inside a time of the statistics) is practically identical across metropolitan and country territories at around 69 people per 10000 . These little levels of distinction among country 


\title{
International Advanced Research Journal in Science, Engineering and Technology
}

\author{
Vol. 8, Issue 9, September 2021
}

DOI: 10.17148/IARJSET.2021.8934

and metropolitan zones are unbalanced to the appropriation of everybody, of which $74 \%$ lives in rustic territories (Asian Development Bank, 2002), characteristic not just of the shortage of ID and screening administrations in provincial territories (Asian Development Bank, 2002; Rao and Reddy, 2004), yet in addition of the avoidance of numerous individuals with inabilities in country territories from the tally. Strangely, this has been ascribed to the absence of complexity in provincial respondents (Dash and Singh, 2006) as opposed to the unseemliness of the device. The issues innate in a clinical model definition are likewise found in the ID of individuals with psychological sickness and mental hindrance. The overview included three tests. Respondents were viewed as intellectually sick if their reaction to just to the first test, and intellectually impeded if their reactions to each of the three were in the positive.

The primary inquiry posed if any relative exhibited trouble in comprehension guidelines or completing exercises like their companions, conversed with oneself, giggled or cried without reason, gazed or was vicious; the subsequent inquiry posed if these practices were seen before 8 years old; and the third inquired as to whether the relative was postponed on explicit achievements. This methodology (1) expects to be a restricted range of practices to recognize either a scholarly problem or a psychological instability, (2) blocks the chance of recognizing an intellectually sick kid or young adult, (3) does not consider individual or social varieties in assumptions for kid advancement, what's more, (4) most essentially, might have simply brought about a person being arranged under psychological sickness as under mental hindrance, smothering numbers for the last class (Kalyanpur, submitted).

How responsive are government's new approaches and projects?

Lacking execution and monetary assets, and a count framework that depends intensely on a clinical model of naming have hampered government drives on comprehensive instruction and brought about enormous quantities of unidentified and unserved kids with handicaps. Since 2003, the public authority has proclaimed three new approaches on the training of individuals with handicaps and executed an extensive EFA program. How much do these new drives react to the inadequacies of the public authority's prior endeavors and the lacunae recognized in the enumeration? This part endeavors to address this inquiry.

\section{Arrangements}

The orders of the Millennium Development Goals have brought about three government arrangements. The Right to Education Bill 2005, drafted by the Ministry of Human Resource Development, actually anticipates authorization (Bhushan, 2006). This Service additionally drafted the Action Plan for Inclusion in Education of Children and Youth with Disabilities (IECYD) in 2005. The National Policy for Persons with Handicaps, under the Ministry of Social Justice and Empowerment (MSJE), continued in 2006.

Given the disarray in understandings of the idea of consideration in prior enactment also, strategy (Singal, 2005), the main commitment of the 2005 IECYD Action Plan4 is its push to explain this. It expresses that: 'while under the Plan of Integrated Education for the Disabled Children (IEDC) as it remains at present, youngsters with handicaps are put in an ordinary school without making any changes in the school to oblige and uphold assorted necessities, the reconsidered IECYD will, conversely, adjust the current actual foundations and instructing approaches to address the issues, everything being equal, incorporating Children with Special Needs' (Service of Human Resource Development, 2005). It perceives the need to move away from a corrective position for lawful infringement with proactive measures to support consistence, and outlines the specialists answerable for executing each yield (despite the fact that courses of events are absent). It stays not yet clear whether this comprehension of consideration can be spread among all partners and the execution smoothed out across every one of the mindful specialists.

Another reformist part of the IECYD Action Plan is the guarantee to give in and pre-administration preparing to customary schooling instructors on handicap and comprehensive training through cooperation with the Rehabilitation Council and the National Council for Teachers' Education, just as to pre-school (anganwadi) laborers in the Integrated Kid Development Services (ICDS) program.

\section{Projects}

Under the World Bank orders suggesting the foundation of EFA programmes, 6 the principal drive on comprehensive schooling, the Scheme of Integrated Schooling for Disabled Children or IEDC (alluded to above), bit by bit expanded its concentration as it was subsumed under nonexclusive provincial turn of events and destitution decrease programs. Under the Janshala Schools program (1998-2004), it made mindfulness about the significance of schooling in low enrolment areas and offered free schooling to 'integrable' kids with handicaps in standard study halls at governmentfinanced schools with transportation and assistive gadgets (Gandhe, 2004). By 2003, under the most up to date EFA drive, SSA, it vowed to oblige other understudies with inabilities inside other option and non-formal tutoring frameworks, and give private and non-private 'connect courses', or temporary projects for mainstreaming, to kids with handicaps who had never been to class (Rao et al., 2005).

Examination of the EFA program, and the IEDC specifically, uncovers that, execution keeps on being divided. By and by, express governments' needs are a factor. For example, in spite of the fact that Madhya Pradesh and Gujarat have 


\section{DOI: 10.17148/IARJSET.2021.8934}

similar quantities of individuals with incapacities (NSSO, 2003), in 2002, Madhya Pradesh had 2165 IEDC schools while Gujarat had just 898 (Rao et al., 2005). Essentially, the 'vote-worth' of a venture is one motivation behind why a recently chosen state government may decide to proceed or stop it (R. Sundar Vadan, Disability Commissioner, Andhra Pradesh Government, individual correspondence, 25 November 2005).

Further, accepted procedures from prior programs are not generally consolidated into later ones. For example, the incapacity agreeable intercessions of the Janshala program, casted a ballot the best on the planet by the UN, for example, staggered instructing which tries not to slander battling understudies, and miniature arranging which makes strong town level inclusion, have not been received by the 2003 SSA program (Gandhe, 2004).

In any case, lately, worldwide funders note that the multi-sectoral approach accepts both a modern degree of coordination just as expert information that may not exist in government organizations (Asian Development Bank, 2002), and a more significant level of investment and support by people with incapacities inside this strategy structure than as of now wins in India (Pinglay, 2005).

They affirm that a more smoothed out approach works with execution, and that, while a multi sectoral allotment of duties may appear to be coherent, the requirement for a multidisciplinary approach in a custom curriculum and restoration administration conveyance might be better presented with combination (Asian Development Bank, 2002; Peters, 2004; World Bank, 2004). In an environment of asset shortage and moderate change, a particularly extreme change of position can scarcely be useful to the Indian government. For sure, the 2006 Public Policy choice to make the Human Resource Development Ministry the nodal organization for the training of people with inabilities, MSJE the nodal office for Policy execution, and ten different Ministries and eight Departments capable for portfolio-explicit execution doesn't demonstrate this change will happen.

\section{CONCLUSION}

Can the public authority give powerful and adequate schools to be impartial to all distraught gatherings? Or on the other hand, when assets are insufficient, do the objectives of amount and quality become totally unrelated? On the other hand, in attempting to meet the two objectives, does it imply that nor is accomplished? Doubtlessly in after the orders of worldwide help organizations, the Indian government is confronted with troublesome decisions and the probability that, whatever the choice, there might be no effective results. Not upholding comprehensive schooling as an ethical basic would have estranged the global guide local area and public inability rights activists, among others, endangering India's situation as an innovator in the creating scene. Be that as it may, in moving towards comprehensive training, there is the danger of distancing the deliberate associations, which oblige a huge level of kids with incapacities, be that as it may, settled in their rehearses, keep on offering uncommon schools.

Eventually, the public authority seems to have fostered its own exceptional reaction towards mollifying all gatherings: it is accommodated to having two equal tracks of instructive frameworks for understudies with handicaps. This construction comprises of government funded comprehensive schools for kids with gentle or potentially actual handicaps who could be obliged in a standard study hall with insignificant help and government funded or then again NGO-run uncommon schools for understudies with moderate and extreme inabilities who might require major curricular changes to be scholastically fruitful (Rao et al., 2005). That the public authority has even recognized the need to teach understudies with moderate and extreme incapacities is seen as a huge achievement also, in fact, a stage towards consideration. This trade off arrangement flies in the substance of worldwide proof that financing the two frameworks all the while adversely influences the nature of both (Peters, 2004); further, when assets are spread over equal frameworks in an environment of shortage, the deficiency is additionally exacerbated (Singal, 2006). The public authority's previous record of helpless execution scarcely help. Two, since higher quantities of understudies with locomotor and visual debilitations are remembered for ordinary schools than understudies with mental hindrance, this expands the isolation of understudies with mental impediment who are not obliged in comprehensive schools.

\section{REFERENCES}

1. Ahuja, A. (2002) Teacher training for inclusive education in developing countries: the UNESCO experience, in: M. Alur \& S. Hegarty (Eds) Education and children with special needs: from segregation inclusion (New Delhi, Sage), 77-96.

2. Alur, M. (2002a) 'They did not figure': policy exclusion of disabled people in India, International Journal of Inclusive Education, 6, 101-112.

3. Alur, M. (2002b) Status of disabled people in India: policy and inclusion, Exceptionality Education Canada, 12(2/3), 137-167. Andhra Pradesh Government (2005) Status of disabled welfare activities in Andhra Pradesh as on 14-05-2005 (Hyderabad, Andhra Pradesh Government).

4. Baine, D. (1988) Handicapped children in developing countries: assessment, curriculum and instruction (Edmonton, Vector).

5. Bhushan, S. (2006) Right to Education Bill faces uncertainty. Available online at: http://www. ndtv.com/template/template.asp?category=National\&templatee.html (accessed 4 September 2006).

6. Brady, M. P. \& Anderson, D. D. (1981) Some issues in the implementation of P. L. 94-142 in the Pacific Basin territories, Education, 103(3), 259-269. 


\section{International Advanced Research Journal in Science, Engineering and Technology}

\section{Vol. 8, Issue 9, September 2021}

\section{DOI: 10.17148/IARJSET.2021.8934}

7. Cooke, B. \& Kothari, U. (2001) The case for participation as tyranny, in: B. Cooke \& U. Kothari (Eds) Participation: the new tyranny? (London, Zed), 1-15.

8. Dalal, A. K. (2002) Disability rehabilitation in a traditional Indian society. Asia Pacific Disability Rehabilitation Journal, $13(2), 17-26$.

9. Davis, M. D., Kilgo, J. L. \& Gamel-McCormick, M. (1998) Young children with special needs: a developmentally appropriate approach (Needham Heights, MA, Allyn \& Bacon).

10. Deepa, A. (2006) Available online at: http://www.indiatogether.org/cgi-bin/tools/pfriend.cgi (accessed 8 August 2006). Films and radio programmes (2005) Available online at: http://www.socialjustice.nic.in/films/txt.htm (accessed 22 April 2005).

11. Gandhe, S. K. (2004) External evaluation of Janshala programme: synthesised report (Pune, Indian Institute of Education).

12. Gokhale, S. D. (1981) Planning for the rehabilitation of the disabled, Indian Journal of Public Administration, $27,8-26$.

13. Harry, B. \& Klingner, J. (2006) Why are so many minority students in special education? Understanding race and disability in schools (New York, NY, Teachers College).

14. Hegarty, S. (1998) International perspectives on special education reform: reaction essay, European Journal of Special Needs Education, 13(1), $112-115$.

15. Jallade, L., Radi, M. \& Cuenin, S. (2001) National education policies and programmes and international cooperation: what role for UNESCO? (Paris, UNESCO).

16. Kalyanpur, M. (1996) The influence of Western special education on community-based services in India, Disability and Society, 11(2), 249-270.

17. Kalyanpur, M. (2006a) Inclusion in India: cultural influences and the transfer of Western special education technology in conflict. Paper presented at the Annual Conference of the America Educational Research Association (AERA), San Francisco, CA, USA, April 2006.

18. Kalyanpur, M. (submitted) The paradox of majority under-representation: constructions of difference in a developing country, Journal of Special Education.

19. Kalyanpur, M. (in press) Cultural variations on the construct of self-advocacy in the Indian context, in: M. Alur \& V. Timmons (Eds) Crossing boundaries and sharing ideas: inclusive education (Thousand Oaks, CA: Sage).

20. Kalyanpur, M. \& Gowramma, I. P. (in press) Cultural barriers to South Indian families' access to services and educational goals for their children with disabilities, Journal of the International Association for Special Education.

21. Malapka, S. W. G. (1992) Educational planning and special education in developing countries: a match or mismatch?, International Journal of Special Education, 7, 188-192.

22. Mattelart, A. (1983) Transnationals and the Third World: the struggle for culture (Bedford, MA: Bergin \& Garvey).

23. Miles, M. (1986) Misplanning for disabilities in Asia, in: K. Marfo, S. Walker \& B. Charles (Eds) Childhood disability in developing countries: issues in habilitation and special education (New York, NY, Praeger), 101-128.

24. Ministry of Human Resource Development (2005) Action plan for inclusion in education of children and youth with disabilities (New Delhi, Government of India).

25. Ministry of Social Justice and Empowerment (2006) National Policy for persons with disabilities (New Delhi, Government of India).

26. Misra, A. (2000) Special education in India: current status and future directions, DISES Journal, 3, 6-11.

27. Ray, S. (2003) Preface, in: National Sample Survey Organisation (Ed.) Disabled persons in India, NSS 58th round (New Delhi, Government of India).

28. Rehabilitation Council of India (2005) Annual Report, 2003-04 (New Delhi, Rehabilitation Council of India). Right to Education Bill 2005 (Draft) (14 November 2005) Available online at: http:// www.pratham.org/documents/RighttoEducationBill2005.pdf (accessed 1 April 2006).

29. Saini, S. K. (1987) Development of education in India: socio-economic and political perspectives (New Delhi, Cosmo).

30. Sandhu, R. (2004) Introduction, in: C. S. Mohapatra (Ed.) Disability management in India: challenges and commitments (Secunderabad, National Institute for the Mentally Handicapped),23-37.

31. Sen, A. (2005) Women and men, in: A. Sen (Ed.) The argumentative Indian (New York, NY, Giroux, Farrar \& Strauss), 220-250.

32. Singal, N. (2005) Mapping the field of inclusive education: a review of the Indian literature, International Journal of Inclusive Education, 9(4), $331-350$.

33. Singal, N. (2006) Inclusive education in India: international concept, national interpretation, International Journal of Disability, Development and Education, 53(3), 351-369.

34. Salma Begum; Sampurna P.. "A Study on growth in Technology and Innovation across the globe in the Field of Education and Business". International Research Journal on Advanced Science Hub, 3, Special Issue 6S, 2021, 148-156. doi: 10.47392/irjash.2021.181

35. Mehak Sharma; Kuldeep Kaur Grewal; Mohua Khosla. "A Review: Planning in the Field of Inclusive Education". International Research Journal on Advanced Science Hub, 3, Special Issue 6S, 2021, 170-176. doi: 10.47392/irjash.2021.185

36. Yeshi Ngima; Dorjee Tsering. "Impact of COVID-19 on Education". International Research Journal on Advanced Science Hub, 2, Special Issue ICAMET 10S, 2020, 34-39. doi: 10.47392/irjash.2020.196 